\title{
A service model for diakonia in the Hervormde Kerk in Suidelike Afrika ${ }^{1}$
}

\author{
M J Manala \& T F J Dreyer \\ Department of Practical Theology \\ University of Pretoria
}

\begin{abstract}
This article reflects on the ecclesial position of the diakonia within the Hervormde Kerk in Suidelike Afrika. The body-of-Christ model is postulated as the basis for a practical theological theory. Koinonia is depicted as a linchpin for Christian caring and sharing towards which, if made aware of its role in poverty alleviation, it would make a meaningful contribution. Ways and means of raising awareness are discussed, after which relevant resources for practical service provision are identified and discussed. The establishment of small groups and the engagement of women and youth groups are cited as enabling actions in respect of the. meaningful provision of benevolent and development services. It is then suggested that the church start, register and run development projects in co-operation with the welfare department, business, development agencies and ecumenical friends.
\end{abstract}

\section{INTRODUCTION}

After the evaluation in part 1 of the Biblical perspectives and theological principles governing benevolent services within the Reformed tradition, possibilities of a theological practical theory in the context of the Hervormde Kerk in Suidelike Afrika [HKSA] are examined in this, part 2. Awareness of the church's role in the struggle to alleviate poverty is raised. A call is then directed to the church, particularly the HKSA, to become a meaningful participant in poverty alleviation and prevention initiatives. Possibilities for practical participation by this church are identified and recommendations with regard to practical implementation are offered with the aim of empowering and energising the faith

1 This article is based on a MA thesis completed in the Department of Practical Theology at the University of Pretoria, with Prof. Dr T F J Dreyer as supervisor. 
community towards committed engagement in poverty relief and the development of the poor.

\section{POSSIBILITIES OF A PRACTICAL THEOLOGICAL THE- ORY IN THE CONTEXT OF THE HKSA}

\subsection{Orientation}

The HKSA is one of the Reformed churches, being the product of the mission work of the Nederduitsch Hervormde Kerk van Afrika (NHKA). The merciful service of the HKSA is, as set out in the "Kerkwet en bepalings", the mandate both of the whole congregation as a body and of individual Christians (Art $5 \&$ Bep 74, $75 \& 76$ ). The deaconate is responsible for organising and providing guidance and motivation for the task. This task is also outlined in the (Buka ya Kereke 1979:154-155). Since 1988, at its four consecutive General Church Assemblies (GCA), this church has been discussing and taking serious decisions, without success, about the need for its practical involvement in benevolent services. Even after putting in place diaconal structures at synodal level, engaging the Hervormde Sustersvereniging (HSV), and instructing circuits and congregations to do the same, as well as establishing two synodal charity funds, nothing concrete has come to fruition in this respect. Banda (1996:978), talking of lack of effective infrastructure, says: "However, some individual congregations of the Hervormde Kerk in Suidelike Afrika, devoid of central control (worse still, in rejection of it) act intuitively to respond to local needs of their communities in so far as opportunities become available." Intuition alone cannot be trusted to be the guiding force for this important mandate of the church. The church should not continue to treat this essential service as if it was an emergency service, but must plan and act proactively so that she can always be available for needy members, citizens and stranded foreigners. The question is: what could be the cause of the problem?

The following are presented as possible causes of this debilitating situation: 
- Non-involvement of members with regard to benevolent and other services;

- An apparent, disturbing lack of the spirit of koinonia and sensitivity to human misery;

- Diaconal structures have been put in place without sufficient church law provisions;

- Reduction of the deacon's task to that of a collector and table server. This reduction goes hand in hand with the official misappropriation of Sunday collections (gifts of compassion) and Holy Communion thanksgiving collections, which are meant for the poor and for church maintenance;

- Wrong perceptions about the status of the deacon (associated with inferiority);

- Absence of service groups and networking co-ordinating structures; non-engagement of experts in relevant fields, both in the congregations and at other levels;

- Illiteracy; lack of knowledge and organisational skills;

- Abject poverty among church members.

- Reliance of the church on cultural structures for provision of care to the poor, widows and the elderly (cf Booysen 1993:60-63; Van der Westhuizen 1993:7879) - structures which are unfortunately falling apart, or have already done so in most areas.

\subsection{Needed practical theological theory}

When these causes of the problem are closely examined, it becomes crystal clear that the root cause of the problem can be located in the practical theological theory underlying the functioning of the HKSA. The HKSA needs to rethink this theory. The shepherd-flock model leads to heavy reliance on office bearers, especially the pastor. In this model members' talents and capabilities remain latent. The metaphor of an engine-driven boat, where only one person is actively involved in the control of the vessel, while others sit idly, fits the praxis theory underlying the functioning of this church. For effective functioning the HKSA needs a model based on the metaphor of an oared boat, where all people on board participate actively to get - and keep the boat - in motion towards the desired destination, with the captain in a facilitating role. This model is manifested accurately in the imagery of the church as the body of Christ, which is founded on 
Scriptural passages like Matthew 20:20-28, 23:1-12, 1 Corinthians 12, Romans 12 and Ephesians 4. This model essentially represents the functioning of the congregation as a genuine koinonia (cf Hendriks 1992:89-107).

In this model of the relationship (with God through Christ and the Holy Spirit, and with each other), authority is not the underlying presupposition (cf also Kotzè \& Swanepoel 1983:93). We need to emphasise and activate the universal priesthood of believers. The Biblical concept koinonia best describes this model. Underlying the koinonia is selfless service for the benefit of the poor and for the edification of believers. It is possible to glean a definition from Hendriks' discussion of the concept koinonia (1992:92) which we think may be quite helpful. It reads: koinonia is a God-initiated intimate association or fellowship in Christ and the Holy Spirit, involving mutual relations and involvement. Such fellowship is characterised by love, service, unity, mutual edification, sharing in each other's suffering, carrying of each other's burdens, joy, order and worship. In this intimate relationship, believers receive love, blessings and hope from God through His Word, and are mandated to give to others. It is in such a context, which is also familiar to that which is known to black people of Africa, that it becomes possible "to see, to feel, and to do" (Banda 1996:974). Van Aarde (1996:962) makes an important contribution to the call for the revitalisation of the praxis of koinonia. He says:

In 'n Christelike geloofsgemeenskap waar gesindheid en optrede op die evangelie van Jesus Christus gebaseer word, behoort die kerk die ruimte te wees waar die "onrespektabele arme" se identiteit getransformeer vanaf 'n nikswerd, 'n nie-persoon (non-person) tot kind van God. In hierdie "huishouding van God" word daar nie net van brood geleef nie, maar van genade, en diegene wat begenadig is, begin as mekaar se "beskermhere" op te tree. Dit is die "transformasie" en "identiteit" waarvan daar in die kerk gepraat behoort te word.

The church is to be concerned not only with the poor as the economically deprived, but also as the spiritually and socially deprived. It is indeed only within the koinonia as described above that both the physical and spiritual dimensions of poverty, as pointed out by Sontag and Van Aarde, can be addressed adequately. This is where love, 
acceptance and community will most likely come out spontaneously. The lively interaction taking place in the koinonia, the love and warmth experienced therein provide very useful opportunities for raising awareness with regard to service and mutual assistance as the God-given vocation of the church and of each Christian.

\subsection{Raising awareness}

We have stated our assumption that if the church could be made aware of the role it could play in the fight against poverty, it would be moved to greater, more committed involvement. That includes making the church aware of the extent of poverty. Raising awareness involves, as a matter of fact, dissemination of and reflection on information. As tools for raising awareness the church possesses an inexhaustible wealth of tools, among others preaching, pastoral care, Bible study, group discussions, and newsletters.

\subsubsection{Preaching}

The importance of preaching as a source mode of proclamation cannot be overemphasised. What Sweazy (1976:4) says in this regard deserves to be heeded: "A church's best forms of service are likely to get their inspiration, aims and promotion from the pulpit. And the best sermons are likely to be extensions of all the church is doing. The conversations, therapies and services rendered to the distressed are continued in the pulpit" (cf also Hendriks 1992:109).

This suggests the degree to which preaching is directly involved in initiating, inspiring, promoting and sustaining church services. The Bible presents benevolent service as an imperative, as a mandate, which the church must obey and fulfil in gratitude for, and as an expression of God's love and mercy offered to us freely in and through Jesus Christ. This message must come out strongly in our preaching. Service to the poor, it must be stressed again and again, is service to Christ himself and is considered for entry into God's kingdom (Mtt 25:31-46). Christians must be made aware through preaching that they have been offered salvation, material possessions and the hope of eternal life and peace, in order that they may share with the less advantaged. The value of the sermon is, in the words of Phillip Brooks (in Sweazy 1976:5), that it provides communication of the truth "through a living, breathing, present human being" in "the midst 
of personalities". This communicated truth frees people from ignorance and activates them towards accepting and doing the will of God. Preaching then draws people to God, to each other and to the preacher. It informs, unites and empowers.

\subsubsection{Pastoral care}

Important elements in pastoral care are instruction, comfort, encouragement, guidance, nurturing and sustenance. The pastor and elders go into the homes of members to mediate the comforting and guiding Word of God to families and individuals. Firet (in Hendriks 1992:108) indicates that the Greek word paraklesis, used to explain the pastorate, expresses the mediation of God's coming to humankind in his or her concrete situation of misery, to free him or her so that he or she can be reconciled with Him and be saved, to live a new life of obedience, as a member of Christ's body within which he or she grows unto spiritual maturity. Members are here made aware of the fact that they are members of Christ's body and share with others in the wealth and gifts of Christ. Members are in this encounter also made aware of the fact that each individual member of Christ's body is obliged to use his or her gifts voluntarily and happily for the edification of others and for the relief of those in distressing situations. Members thus become aware of the obligation and role they have, namely to actively love God and fellow humans.

\subsubsection{Bible Study}

Bible study is one method of communicating the gospel in a dialogical manner. Relevant Scriptural portions and themes, based on the needs of the congregation, should be identified and treated in smaller Bible study groups. Small group-based Bible study is, in our view, most effective because participation of members is more feasible in such groups. With a view to the hypothesis of this study, the following themes could be suggested: A living faith results in life-giving deeds to others; Loving, caring and sharing are my obligation; I have received much from the Lord, and must therefore give generously to others. Through Bible study, members can be motivated to love, serve, 
give and be sensitive to the needs of others both within the faith community and outside of it.

\subsubsection{Group discussions}

The issue of poverty must, in view of our poverty crisis, top the priority list of issues identified for discussion. As much information as possible on poverty as well as on approaches and strategies to combat poverty must be obtained for discussion by groups, especially the deacons and other organs of support tasked specifically with the generosity and hospitality mandate. Statistical data about the extent of poverty within the congregation, must be tabled before the meeting of the congregation for information, discussion, and a decision on required action. The character of the work of the deacons, the content of the work, that is: what, how, where and why questions, should be discussed (cf Romein 1981:88). The Word of God, church law, confessional documents and the church's decisions in respect of the church's merciful service, should form the golden thread that runs through discussions. This will help direct discussions and make it possible for discussion groups to review, correct and recommend amendments to existing methods. For the sake of awareness-raising among church members, both as a body and individually, it is extremely important that information be communicated regularly from these discussion groups to the church. This information should also be sent to partners such as the NHKA, who should be moved to offering assistance in whatever way possible. The issue of poverty must also be discussed at circuit and synodal levels as well as in circuit conferences and synodal congresses of organs of support like the HSV and the Hervormde Youth Movement (HYM). This will also motivate these organs of support to get actively involved in the service.

\subsubsection{Congregational and church newsletters}

Information about the extent of poverty and actions taken in congregations to combat poverty can be disseminated through congregational newsletters to members, the synodal office, partners and community projects. The information will, apart from raising awareness, also inspire interest. Appeals for involvement of members and interested community members can also be made through the newsletter. At the synodal level, the 
church will have to concentrate on giving information about the general poverty situation in the church and the country. In addition, information will have to be provided about church action and structures as well as about government structures and policies, including giving guidance as to church co-operation with the government.

\section{EVALUATION}

When church members become aware of their mutual belonging to the body of Christ the church - they are bound to grow into an obedient, grateful and mutually caring community.

The creative, informative, uniting and empowering authoritative Word of the living God places the faith community in the loving presence of the merciful God and moves Christians to reach out to those poor and helpless people whose plight is calling out loudly to them. Christians thus become challenged and are made aware of their corporate role and responsibility.

Awareness leads to obedient acceptance of responsibility, which necessitates an identification of resources for the task at hand.

It is obvious that, for the HKSA to be able to get involved in the nurturing and support of the poor, its membership must be duly made sensitive to the misery and needs of the poor.

Aware of its role, the congregation/church can be a very important instrument in poverty relief and human development, both physically and spiritually.

Are there resources for the HKSA to start with the fulfilment of its God-given mandate for compassionate service? The answer to that question is an unequivocal yes. We accordingly identify these resources in the next paragraph.

\subsection{Identification of resources}

- The HKSA has members - men, women and young people with different talents and capabilities. These talents need to be identified, nurtured and employed in God's service. There are also among these members professionals, for example medical doctors, teachers, social workers, health workers, and lawyers who can serve as resource people. Some members are well off and can help with financial 
and other resources to help the poor. All members are, however, responsible for helping the church meet the needs of the poor.

- The church has church buildings, premises, electricity and water supplies throughout the country, more especially in urban areas, from which soup kitchens can be run and administered to feed the poor, the elderly and street kids, as well as crèches. Church premises also offer space for gardening projects, which can help meet nutritional needs of poor families and individuals, especially malnourished children.

- Familial structures still exist, more especially in rural areas, which can be used to care for poor relatives in the spirit of the black cultural mutual helpfulness and of the African Renaissance. The church can give to these families spiritual, moral and modest financial support where possible, and direct them to the welfare department's poverty relief programmes as well as to other aid organisations.

- Community development projects can be approached for assistance on various issues, including strategies of community mobilisation, fundraising, project planning, drafting of project proposals etc. RDP-related community projects can be requested to provide training of church development workers. and other necessities. At ecumenical level, churches which have the culture and practice of caring for and developing people as well as existing projects can be of great assistance.

- The government, which is the institution that is by far the most committed to the cause of all the poor citizens of this country, can and must be approached for financial subsidisation of identified and well-researched welfare programmes and institutions, run or envisaged by the church.

We are convinced that with such helpful resources there will be light at the end of the tunnel for the struggling HKSA. Possibilities which have become more apparent should serve to motivate and empower the church to get out of its state of paralysis in the midst of so much suffering. Coupled with an effective practical service model these possibilities can transform the HKSA into an actively caring, sharing and hospitable koinonia. 


\section{THE PRACTICAL SERVICE MODEL FOR IMPLEMENTA- TION OF THE BENEVOLENT SERVICE OF THE CHURCH}

Based on the body-of-Christ model, in which the pastor and office bearers have the role of guiding the body, our service model will have to involve other services, individuals and groups. Here we will only take a cursory look at the role of worship (liturgy), church law provisions, family, ward, service groups, organs of support and how to access the government's and other organisations' welfare and development aid for the poor. We will also mention in passing the "stokvel" and the burial society phenomena as possible church projects.

\subsection{Worship (liturgy)}

The church's worship is rightly called the heart of congregational life and work. It is indeed the central activity of each congregation. No wonder Garett (1973:1) calls it: "The life blood of the church". The most important factor about Christian worship is God's declared and actual presence in the worship of the faith community. God's presence is an act of his free grace shown to all His children - the rich and the poor alike. This grace is manifested in the service of the Word and Sacraments. The rich and the poor come into contact with one another as brothers and sisters. They are brought to the same level by God's grace (The worker Sunday Campaign 1999:2). The planning of the church's worship should be carried out in order to facilitate its dialogical nature. This means that all that happens in the worship of a congregation should take cognisance of, and involve, members and their existential situations. The preaching will have to cover all three areas of human life, namely cognitive (of the mind), affective (of feelings), conative (the doing aspect). Sound guidance towards true faith and works of faith can only be effectively given if it is done this way. The work of the Holy Spirit is only possible through the Word of God. Here, in worship, humankind is offered communion with the living God and with fellow human beings through God's Word and Spirit. The plight of the unemployed, the poor, the widows, the orphans, strangers, etc. comes to the attention of other believers most directly in worship, and inspires compassion and helpful mutuality. 
It is surprising that the HKSA has not been able to connect worship - leitourgia with charity - diakonia. It is high time the HKSA rediscovers the caring and charitable atmosphere of Christian worship, especially with respect to Holy Communion. The setting apart of gifts of compassion, collected on the first day of the week (Sunday) (1Cor 16:1-3) - and Holy Communion offerings specifically for the starving saints - we think would be the right response of the church, in a small but compassionate way, to the crisis facing us. If the church can start doing this, it can facilitate, albeit on a small scale, prospects or the possibility of starting and sustaining practical caring by, for instance, the forming of soup kitchen projects in the church's congregations. This practice is followed in other churches, among them the NHKA, and has also helped with congregational donations to the church's welfare institutions as well as to others in the community. Church worship offers the right occasion for such acts of love to be inspired and acted upon. Talking without action will bring no solution to the poverty crisis, and the HKSA cannot continue to act as though it has been exempted from loving. The church will, if it wants to break the ice of insensitivity, start giving this money for feeding the hungry and helping the helpless. Pirozzi (1997:348) and Tucker (1995:51-64) point to the fact that effective Christian giving to the poor is dependent on this connection between leitourgia and diakonia.

\subsection{Church law provisions}

For good organisational functioning, the church needs guidelines. These guidelines are often written down in the church law or order. The church law of the HKSA has shortcomings which make it difficult for the deaconate to function as it should. There are no regulations or provisions governing the co-ordination, tasks, functions and responsibilities of diaconal structures like the synodal diaconal board, circuit diaconal board, or diaconal committees at the level of the congregation. The church law, it seems, was written with no consideration of the need for service groups and co-operation with other organs of support, welfare organisations and the government. The church must as a matter of urgency give attention to these defects, otherwise many of the decisions taken by the deaconate will remain unimplemented because of lack of co-ordination mechanisms. A well-formulated church law will in our view facilitate the smooth functioning 
of charity and other structures. The family is another structure to which attention must be given in the building of a functional koinonia.

\subsection{The family}

The family is accepted as the basic or the smallest unit of society (Jones 1996:1-8; Burger 1996:121). Hendriks (1992:95) writes about the family in similar terms, in relation to the church: "Die gesin is God se mikro-gemeente". The importance of the family is duly emphasised in all the above-mentioned sources. It is seen as impacting on society more directly than any other institution (Burger 1996:121) and as the foundation of the process of building up the church (Hendriks 1992:95). This evidence in respect of the fundamental nature and importance of the family, both to the society and the church, suggests that it is obvious that any attempt at community development and church building, should put family development high on the agenda. The HKSA cannot do otherwise. The family is one of the most important pillars of church life and selfexpression.

The deacon must help families in his/her ward to learn the culture of wrestling with the Word of God in family devotions. This requires an effective inculcation of discipline in respect of time management in the face of the mass media for example television which makes larger and larger claims on more and more families' time. That can be achieved through regular visits and ward prayer meetings and functions. The family must learn serviceability and communality over against selfishness and individualism. The congregation should be a community of mutual caring and sharing, and these can only become a reality if they can be started and maintained successfully in the family. The love of God and neighbourly love should be stressed in discussions with families in the ward. That should in turn help families to teach their children in word and deed the love of God and of others, as well as respect and compassion for all people, regardless of their economic, racial or social status.

Effective development of the family as an important pillar of the koinonia, could provide wonderful opportunities for the church's benevolent service. In the context of black culture, the family in its nuclear and extended units has always been seen as the basis for the support of poor relatives. Today it cannot be claimed that that position 
remains intact. Materialism and the resultant individualism seems to be gaining momentum, more especially as a result of urbanisation with its gain motive and pressure to achieve (cf Hendriks 1992:96). This should be addressed in order to develop the family into a unit that focuses more on God's will and sensitivity towards human suffering. The family can then once more become the centre of compassion and hospitality. And if more such families exist in a congregation, we will surely have a more compassionate and hospitable congregation that takes care of the poor, both spiritually and physically, because family care by its very nature caters for the entirety of one's needs. One can go further and say if many such congregations are found in a church, we will then have a compassionate and hospitable church with Christ and his concerns as its centre and focus. And then the expression: "mofiwa, fa ba bangwe ..." (stated as part of the title of our study - part 1) becomes a jubilant hymn and practical service of a Christ-saved and Christ-centred church. When many families become care centres for the poor, the church can assist these families with Christian community skills, moral support and minimal financial support if and when possible. The deaconate will decide in conjunction with the church council on how to assist families which care for the needy. The church can also direct the needs of these families to the government via RDP structures and the welfare ministry. Another micro-congregation (Hendriks 1992:95) which needs to be developed into an active caring and sharing unit, is the ward. The ward needs to be turned into an intimate, active and caring unit.

\subsection{Turning the ward into Christ's extended family unit}

The ward consists of a group of families belonging to a congregation, living in the same neighbourhood. A ward must be a manageable entity, and must preferably be a small unit. An average of ten visiting points or homes per ward (Kupa s a:3.1):

Om die gemeente doeltreffend te kan bearbei, moet die kerkraad die gemeente in kleiner wyke verdeel. 'n Gemiddeld van ongeveer tien besoekpunte of huise per wyk skep beter geleenthede tot beter kommunikasie tussen die diaken of ouderling en die lidmaat.

Die diaken/diakones moet die lidmate binne sy/haar wyk goed ken. $\mathrm{Hy} / \mathrm{sy}$ moet hulle maandeliks besoek. In die geval van nood of lyding moet 
hy/sy so gou moontlik by die betrokke lidmate aanmeld. Hy/sy moet die wyksouderling en die predikant onmiddellik in kennis stel van die nood. Hierdeur kan ander instansies soos die diakonaat en die kerkraad ook verslag kry van die betrokke toestand.

Hy/sy moet met begrip en meelewing by probleme in die wyk optree, en as skakelfiguur die mededeling in hierdie verband aan die ouderling/ predikant deurgee. Hy/sy moet in staat wees om die verslag aan die kerkraad te kan gee.

Die ouderling en die predikant sal die diaken behulpsaam wees in probleme van geestelike aard soos, dood, siekte, gesinsverbrokkeling, alkoholisme ensovoorts.

Probleme van materiële aard moet so gou moontlik aan die diakonaat en die kerkraad gerapporteer word. By al die probleemgevalle moet daar altyd vertroosting uit die Woord van God gebring word.

By die aflegging van die geloofsbelydenis het elke lidmaat 'n vrywillige maar ook 'n bindende en onherroeplike belofte voor God en die gemeente gedoen om met dankbaarheid deel te neem aan die aktiwiteite van die gemeente tot opbou van die kerk. Op grond van hierdie belofte sal elke lidmaat sy/haar offergawes met blymoedigheid gee (vgl Die Diensboek). Dit is die taak van elke diaken/diakonis om gereeld en betyds by te wees om hierdie offergawes te kan insamel.

According to Koekemoer (1980:60), a group of twelve families is ideal for the creation of better communication opportunities between the deacon and members. The ward can therefore also be classified as a micro-congregation, with reference to Hendriks' description of the family (Hendriks 1992:95). It is a family of families in a smaller area. Its size must be kept small and manageable. Ten houses should remain the ideal. Such a ward provides the more likely unit within which intimate relations can be developed and nurtured.

We envisage a ward that lives and works as a family unit, praying, rejoicing, suffering and agonising together. This can be achieved by concentrating on building relationships within the ward and by creating opportunities for regular interaction between the deacon and members and among members themselves. To this end the deacon of the ward should, in addition to his/her monthly visits, organise regular ward 
meetings, functions, prayer meetings and Bible study sessions in members' homes on a rotating basis. Caring services have the ability to create very intimate relationships. When people for example work together to help a bereaved family, raise funds for and with the poor, visit the sick at home and in hospital, the prisoners, orphanages, homes for the aged, places of safety and other welfare institutions, there grows among them a more intimate relationship. The koinonia ties and sensitivity intensify within a caring atmosphere. These services must be organised and carried out on a more regular basis and extended beyond services to members of the HKSA. The Word of God, love, warmth, acceptance, clothes and food can be offered during these activities.

\subsection{Service groups and organs of support}

Envisaged services can be effectively offered if the ward has different service groups, each with a specific focus. Groups should involve members in accordance with their God-given talents, availability and commitment to Christ and his work. These groups would focus for example on care of the aged, children and youth, the socially troubled, the sick, the economically poor, prisoners, orphans, aliens, et cetera. Women and youth groups can be utilised effectively in these service groups. Women are the most resourceful group in terms of their inclination towards caring and with inexhaustible enthusiasm for participation in church work. The participation of women is evidenced both in the Bible ( $R m$ 16:1, Ac 9:36 etc) - for instance, in the persons of Phoebe, Dorcas and others - and in the HKSA, where women were deployed as additional workers from the early years of establishment, as noted by Banda (1996:105). It was also through the caring services of three women in the Cleveland "mine dump" that the Christian Service Foundation was born, which later joined with the Rhema church to form the Rhema Christian Service Foundation (Rhema Christian Service Foundation:1). The Rhema Christian Service Foundation offers an array of services to the aged, children, the sick, the chronically ill, the hungry and the homeless. Young people are also a workforce that needs to be developed and engaged in the care of others. The involvement of young people will, apart from assisting the poor, also meet their need for group belonging and preference for doing (activity) rather than just dogma. This does not however suggest that men have to be left out in the formation of these groups. The emphasis on the 
inclusion of women and young people presupposes the traditional, undeniable involvement of men in all church services. Through regular interaction around discussions of and reflection on God's Word and practical service as referred to above, a lively caring ward will develop and the poor, the sick, the elderly, et cetera will be helped and God be praised. The church could in this way be energised towards meaningful participation in poverty relief and prevention programmes and activities. Service groups in the ward must function under the guidance and motivation of the deacon and the congregational deaconate, all of which work under the supervision of the church council.

\subsection{The Hervormde Sustersvereniging}

The potential, capabilities and reliability of the HSV as caregivers, organisers, fundraisers and people of prayer have not been sufficiently exploited for benevolent service in the HKSA. Although the HSV had not defined itself as a diaconal organ of support until included in the deaconate by the 1991 GCA, it covered in its constitution areas of service which have a strong diaconal character. The following sections of its constitution are examples: 3.2: "Promotion of services of love..."; 5.5: "visit the sick and the destitute, to comfort families; visit the bereaved". These include sections about programmes to be followed in these visits (9.8 \& 9.9). This diaconal character and fundraising prowess, care and prayerfulness of the HSV are in our view, important indicators of the potential diaconal value of this organ. The NHSV (NHKA's women's union) is a registered welfare organisation and, apart from diaconal services in the congregation and support to the congregational deaconate, it also forms a liaison between the government and the GCA on matters affecting its field of service (Koekemoer 1980:25). The HSV can also be fully engaged and registered as a welfare and diaconal organisation to effectively render government-subsidised benevolent services. Qualified social workers with government-subsidised salaries can provide invaluable services in this regard. Such arrangements will undoubtedly present the church with possibilities and opportunities for meaningful involvement in the fight against poverty. That will then replace the usual talk-shops with creative workshops. 
Many people have made appeals for a paradigm shift from charity to development, among others Mpanza (cf 1996:968-967). This should however not imply that immediate needs of communities should be neglected (Js 2: 15-17).

\subsection{The Synodal development body}

Development and empowerment are the two buzzwords as we enter the $3^{\text {rd }}$ millennium. "The poor must be developed to be enabled to help themselves" is the latest battle cry in the search for solutions in attempts to combat and prevent poverty. Appreciable as it may be, the shift seems to lack the necessary twofold focus on both the immediate and longterm needs of the poor. Demands for a paradigm shift from the giving of alms to development, in our opinion, presuppose a separation of this inseparable service, an overrating of development as opposed to charity. The church cannot follow such an approach. It cannot stomach the idea of giving seed to a hungry person and sending him/her away to plant the seed and wait for it to germinate, grow and bear fruit. In other words, the church is not prepared to postpone addressing immediate needs of the poor under the guise of development programmes, thereby prolonging their suffering. Mkhabela (1996:11) warns and argues against such a trend: "I argue, even at this time of our history that it is not an either or but a balance between the two." We agree with that position. The church's development programmes should, though, be Christ-centred; in order to be people-centred.

The church should enter the development field with a broader perspective, mindful of the need for charity and empowerment as well as spiritual enrichment and moral reconstruction. Development projects under the guidance of the church will therefore busy themselves with development programmes while simultaneously dishing out the Word of God, creating personal contact and an atmosphere of warmth, love and acceptability, which are in our view more empowering than any programme which is purely developmental. Such programmes will thus also address both church and community members' social problems through the use of pastors and other professionals.

For the HKSA to become a meaningful participant in the fight against poverty, it will have to put in place and register as a welfare organisation, a development structure, which will liase with other development agencies such as the government, donors and 
church committees, commissions and auxiliary bodies. Such a development body will help the church with needed research on development theories, causes of poverty, the development of theologically sound strategies and approaches to combat poverty. It will also link up with experts in various fields dealing with poverty relief and development for vital information and training of human resources within the church and adjacent communities. The development body will also be responsible for advising the Commission of the General Church Assembly, the Synodal and Circuit diaconal boards and organs of support as well as congregational deacons' committees and service groups. It will design relief and development courses and organise workshops and seminars on behalf of and together with the Commission of the General Church Assembly and other church structures. Such a body, which must also link up with the NHKA's Ondersteuningsraad, to share the latter's experiences and guidance, will in our opinion unlock meaningful action leading to assistance and development of the poor, to ultimately contribute positively to the fight against poverty. It will urge, motivate and guide congregations to start and run development projects which bring the poor together for community as well as self development and for sustainable income generation. The body will also have to find ways of establishing schemes like stokvels, burial societies, et cetera, as meaningful fund generating and job creating mechanisms for the development of church members and township and rural communities. The question of the establishment of a wing which will raise funds for bursaries and study loans in the development drive and action of the church should be treated as an absolute implerative if the country and her poor are to benefit both in the short and long term. The HKSA must indeed urgently equip its members and service structures for God's service. Some of the areas which need to be covered in equipment programmes, should include the following:

- The contextualisation of the Biblical message to address our poverty context.

- The church must make use of its buildings and qualified teacher members and the elderly as well as other concerned members to promote the culture of learning and the quality of its children's education. That can be achieved by providing afterschool lessons in the church building, overseeing and helping children with their homework. That will ensure improvement of examination results in the short term and a better future in the long term. Literacy training should be seen and 
offered as an important instrument for development even of the so-called ultrapoor.

- The church must infuse Christian ethics to help people to accept work as God's calling and to move away from the dependence and entitlement syndrome; to accept sacrifice as a lifestyle; to regard responsible child-bearing and rearing as prerequisites for having affordable, manageable and quality families and to avoid the frightening prospect of the depletion of natural resources (cf Van Rooy 1999: 252). Programmes to develop and live the values and attitudes of love, mutual respect, warmth and acceptance are needed. These attitudes should be inculcated in both the rich and the poor. Youth programmes can be very helpful in combating gangsterism, promoting responsible citizenship and peaceful surroundings resulting in much-needed productivity, which has the potential to remove from the country the scourge of poverty.

- Job-related, small, medium and macro business-related training is needed with respect to inter-personal relations, human resources and financial management, et cetera. Project planning, monitoring and evaluation should form part of equipment programmes.

- The church should maintain a strong interactive, critical relationship with government and community structures in order to exert a helpful influence which may also help curb corruption and greed which help divert financial and other resources from the poor. The church could in this way offer herself and the resources at her disposal as a channel through which government departments, development agencies and donors could reach out to the poor with means for survival and development. This relationship should however, not paralyse the church into a passive channel for government and development agencies' services to the poor. It must be through its own initiated and sustained programmes and projects that it channels resources, from elsewhere, to the poor. Transformation of people, of both the materially rich and the poor, into God's children, will materialise only if the church remains rooted in the truth of the Word of God, which is truly saving and liberating. 


\section{CONCLUSION}

It should now be clear that the HKSA, even though a poor church, can with commitment, in obedience to God's will and as expression of God's mercy, become a meaningful participant in the fight against the scourge of poverty. The being and character of the church as diakonos and koinonia have proved beyond any doubt to be potentially most energising with regard to the church's lifestyle of humble but committed service, caring and sharing. We are convinced that the following should move the church to meaningful involvement in the alleviation of poverty: awareness of the extent of poverty; the importance of the church's role in the alleviation thereof; and the use of well-equipped organs of support and working groups, as suggested above.

We conclude with a serious wake-up call to the church in general and the HKSA in particular, a call that should be difficult to ignore. This we do by quoting a paragraph from an article by Olivier (1998:1) entitled Do we really care about what happens to our desperately poor?:

Have you had lunch today? Well, Miller (1990:8)/claims that during your lunch hour "at least 2,300 (probably 4,600) people died prematurely from starvation, malnutrition and or poverty related diseases." By the time you eat lunch tomorrow, he says, "at least 55,000 (probably 110,000) more will have died." "This death toll," he states, "is equivalent to 137 to 275 jumbo jet planes, each carrying 400 passengers, crashing every day with no survivors." And in our own country where "nearly half the people live below the poverty line" and half of these poor lack "even the means of subsistence" (The World Bank 1994), we wonder how many busloads of these very poor people have today died because there was either no one who really cared about their wellbeing or none of those close to them who had the means to take care of their needs. We live in a world "cruelly divided between the desperately poor and the overly rich, the hungry and the overfed" (Agarwal 1991:131). Do you and I really care about what happens to our desperately poor?

Later in the above-mentioned article, Olivier sees the solution in the massive undertaking by all sectors of society to liberate the poor by means of whatever aid possible. What is remarkable in this view is that the churches (religious groups) are represented as having a major role to play. True, this is the time for the HKSA to come 
in, to show and offer mercy as representative of Christ ( 2 Cor 5:20), yes as Christ's own earthly historical form of existence. We have identified and explored possibilities which can facilitate meaningful involvement of even poor churches such as the HKSA. God's love and mercy must radiate also in this poor but God-loving and God-fearing church. To achieve this, the following responses, which are in our view decisive for meaningful service, are recommended:

The church, that is the HKSA must urgently take practical steps to transform its service model from the shepherd-flock model to the body-of-Christ model, in which the role of leadership is to guide, facilitate and energise membership towards the achievement of goals. This entails giving special attention to the development of the priesthood of believers in church law and in practice.

The HKSA must, in the light of Biblical perspectives ( 3.2 above) and theological principles (3.3.1 above), practically promote reconciliation and meaningful interaction and co-operation between the rich and the poor. From our discussion of needed practical theological theory (4.2), it has become clear that relationship - and neither authorisation nor revolutionary confrontation between the poor and the rich - is vital in the fight against poverty. It is in that light that Kazantzakis (in Sontag 1996:613) declares: "I am not going to kill sin by killing the sinner." It is a relationship of support and meaningful co-operation which is needed, and not hostile confrontation.

The HKSA will have to start, register and run development projects and institutions. For this to happen the HKSA will have to adopt, adapt and develop some projects already known to communities, depending on their effectiveness, for example the burial society, and creatively start new ones to address the specific needs of communities. This will necessitate the training of church development workers and the use of professional social workers, for the sake of which the church will need to tap into government and the NHKA's resources. The use of pensioned teachers and unemployed members of the church for education, the running of crèches, afternoon education and gardening projects in church buildings and on premises belonging to congregations respectively, should give the church a good kick-start. 


\section{Works consulted}

Banda, Z J 1996a. From open resistance to cautious involvement: The emergence of mission in the Nederduitsch Hervormde Kerk van Afrika. MTh dissertation, University of South Africa.

Banda, Z J 1996b. Response to Rev S P Mpanza's paper on the role of the church in the struggle againstpoverty with reference to the Reconstruction and Development Programme. HTS 52(4), 972-980.

Booysen, D J 1993. Die diens van barmhartigheid in die praktyk, in Booysen D J (ed), Die diens van Barmhartigheid, 50-65. Pretoria: Kital.

Buka ya kereke, 1979. Bloemfontein, 152-158.

Burger, A P (ed.), 1996. Ubuntu: Cradles of peace and development. Pretoria: Kagiso Publishers.

Garett, T S 1973. Christian worship: An introductory outline. London: Oxford University press.

Hendriks, J 1992. Strategiese beplanning in die gemeente: Die beginsels \& praktyk van gemeentevernuwing. Wellington: Hugenote uitgewers.

Hervormde Kerk in Suidelike Afrika. General Church Assembly. Minutes. Deaconate, 1991, 1994, 1997.

Hervormde Sustersvereniging, 1988. Constitution, sections 3.2, 5.5, 9.8 \& 9.9.

Hope in the midst of unemployment. Jubilee 2000, South African campaign. The Worker Sunday campaign, May 1999.

Jones, B 1996. The role of the family, church and school in fostering attitudes of peace and development, in Burger 1996:1-8.

Kerkwet en bepalings van die Hervormde Kerk in Suidelike Afrika, Pretoria. Artikel 5.

Koekemoer, J H (ed), 1980. Handleiding vir diakens. Pretoria: HAUM.

Kotzè, D A \& Swanepoel, H J 1983. Guidelines for practical community development. Dibukeng: Pretoria.

Kupa, A M (ed) s a. Handleiding vir diakens van die Hervormde Kerk in Suidelike Afrika.

Mkhabela, B 1996. Challenges facing the country and NGO's, in S A C C Indaba for Church Development workers Conference, 9-14. 
Mpanza, S P 1996. The role of the church in the struggle against poverty: A Hervormde Kerk in Suidelike Afrika perspective. HTS 52(4), 965-971.

Olivier, D F 1998. Do we really care about what happens to our desperately poor? Faith \& Earthkeeping, 1-2. Goldfields University of South Africa.

Pirozzi, E R 1997. Toward locating the separation of charity from Eucharist, in the ancient church. Worship 17, 335-349.

Rhema Christian Service Foundation. Yeoville, Johannesburg.

Romein, A 1981. Diakonaal huisbezoek, in Noordegraaf, A \& Romein, A, Christelijke hulpverlening, 80-95. 's Gravenhage: Boekencentrum BV.

Sontag, F 1996. Who are the truly poor? Francis, Boff, Kazantzakis. JETS 39(4), 609615.

Sweazy, G E 1976. Preaching the good news. New Jersey.

Tucker, K B Westerfield, 1995. Liturgical expressions of care for the poor in the Wesleyan tradition: A case study for ecumenical church. Worship 69, 51-64.

Van Aarde, A G 1996. Armoedekultuur: Die leefwêreld van Nuwe Testament en die situasie in Suid-Afrika vandag. HTS 52(4), 947-964.

Van der Westhuizen, H G 1993. Barmhartigheid en sending, in Booysen 1993:66-83.

Van Rooy, J A 1999. The Christian gospel as a basis for escape from poverty in Africa, In Die Skriflig 33(2), 235-253. 